\title{
Modern Development Tendencies in Georgian Construction Law
}

\section{Introduction}

Tbilisi, the capital of Georgia has become a construction testing ground over the last few years. Since 2013, 2500 new construction permits and about 1000 reconstruction permits have been issued annually ${ }^{1}$. At first sight, such a growth rate of construction may seem to have a positive impact on the economy of the country in a short-term outlook, but from the perspective of sustainable development, it cannot counterbalance the "urban suicide" - the worsening of the living environment and neighborhood disturbances (e.g. damaged or demolished buildings, violation of the insolation norms, property devaluation) and other similar tendencies. These problems do not result from the local government policy only; they have been greatly encouraged by the liberal legislation regulating this field. And this is why the discussions about reforming the construction legislation in Georgia have recently become more lively ${ }^{2}$. The key issues of the reform are: strengthening the spatial and urban construction planning; cancellation of the special zone agreement

\footnotetext{
${ }^{1}$ www.tas.ge (accessed: 12 I 2018).

${ }^{2}$ In this regard, we should specially mention the task meetings within the framework of the initiative of the Ministry of Economy and Sustainable Development of Georgia, which were held on permanent basis in 2011-2015, with the financial support of the German Society for International Cooperation (GIZ). For this and other related issues, see K. Kalichava, Impact of Construction Law Reform on the Freedom of Business in Georgia, "Perspectives of Administrative Sciences" 2016, no. 2, pp. 43-50.
} 
which totally contradicts the planning concept; determining the basic quality requirements for buildings and construction materials; regulation of the major professions involved in the construction activities. The goal of this article is to analyse the aspects highlighted above, in the contexts of past experience and the current and future reform.

\section{Briefly about the Genesis of Georgian Construction Law}

\subsection{The Soviet Period}

The characteristics of construction laws which existed in Soviet times were mostly determined by the economic system of that period. The Soviet economic system, as it is known, was based on the principle of "social ownership". The state itself was acting as the principle industry player. The fields like house-building, production or trading and services were generally subject to public administration and were monopolised by the state ${ }^{3}$. In the Soviet economic system there was no need for modern methods of administration of the relationship structure between an administrative organ and a citizen. In the construction field a citizen simply had no right to set up a private business (except for building a house for private use which was also limited ${ }^{4}$ ) and respectively no legal guarantees of realisation of such rights existed. Moreover, the Code of Administrative Offences in force at that time, which is now rightly called a "Soviet truncheon", envisaged liability for any attempt to acquire an individual right which contradicted the socialist economic order. Furthermore, the Soviet administrative (construction) law was an organisational law ${ }^{5}$, which helped to strengthen the operation of the state machinery.

\subsection{Post-Soviet Period}

After the dissolution of the Soviet Union, when Georgia faced the need of creating governing systems and legal institutions directed at free market economy, it became clear that the historic heritage of the Soviet system

\footnotetext{
${ }^{3}$ G. Eremov, Soviet Administrative Law, Tbilisi 1984, pp. 170-178 (Georgian).

${ }^{4}$ The key rules of conduct were incumbent Soviet construction norms, so called СНиП.

${ }^{5} \mathrm{G}$. Winter, Verwaltungsrechtsentwiklung und ihre ausländische Beratung in Transformationsstaaten, Das Beispiel Georgiens, VerwArch, 2010, p. 409 et seq.
} 
did not provide enough basis 6 . Therefore in the 1990s there were adopted new laws on urban planning and construction permit but their contents were still based on Soviet experiences ${ }^{7}$. The situation significantly changed after "Rose Revolution" in 2003. The legislation adopted in that period was mostly deregulatory and business oriented. Thus, the rule of law was an issue before, but within the new approaches the problem of legislative proviso appeared, which meant that priority was given to the cancellation of the existing legislative regulations. It caused numerous problems in regard to diminishing the role of the urban planning concept, so called "coefficient trading", non-transparent procedures, disproportionate allocation of discretionary authority to the administrative organs (exaggerated scopes of this authority have been granted in some inadmissible cases while sometimes it is not granted at all when it is really necessary), lack of quality requirements for buildings and construction materials, etc. ${ }^{8}$ Another problem is insufficiency of legislative proviso which causes accumulation of essential decision-making powers within the executive government without limitations of parliamentary laws, which evidently, contradicts the principles of a democratic and legal state.

\section{Basic Challenges of the Current Legislation}

\subsection{The Exception for Exceeding the Parameters on Some Building Sites (i.e. the model of "Coefficient Trading")}

One of the vital issues of Georgian construction legislation is repudiating the concept of planning in urban development, and the mechanisms of exceeding parameters on some sites. Therefore, at first glance the statutory type of zoning may seem to be a prerequisite for solid city planning, and any third party should be able to assume a building of what function and intensity may be built on a neighbouring site. However,

${ }^{6}$ F. Böhm, C. Weigand, Rule of Law in Public Administration: Building Up an Administrative Legal System in the South Caucasus, in: Transformation, Politics, and Implementation: Smart Implementation in Governance Programs, ed. by R. Kirsch, E. Siehl, A. Stockmayer, Baden-Baden 2017, p. 223.

${ }^{7}$ Transfer from the Soviet system to the post-Soviet one had an impact on almost every sphere of public life - democratisation, development of market structures, development of public institutions and etc. hence, it was impossible to ensure high quality of these objectives simultaneously.

${ }^{8}$ K. Kalichava, Impact of Construction Law Reform ..., pp. 43-44. 
the established practice shows a completely different picture (recently) (especially since 2009). The analysis of the situation in the capital city as well as other big cities makes it clear that the authorised bodies have been trying to hide behind the statutory exceptions whenever there is a possibility to increase the construction intensity coefficient (the intensity coefficient is used to define construction parameters on certain territories, and includes but is not limited to the building area, height, greening, etc.). However, the court practice unambiguously shows that such acts issued by authorised bodies are groundless which itself is caused by the nature of exception norms. Although, as it may seem, the Law of Georgia on Spatial Development and Urban Construction determines normal and acceptable criteria for making just exceptional decisions, ${ }^{9}$ which are also subject to judicial review, ${ }^{10}$ unfortunately the opposite practice has developed. There was a construction dispute, which was also the only court case on the construction intensity coefficient, ${ }^{11}$ heard by the Supreme Court of Georgia and the decision of the Court of Appeal was upheld. And in that case the Court of Appeal made a very important explanation which may be general for any other construction dispute where the intensity coefficient is an issue. The Court of Appeal underlined therein the importance of the element of justification for confirming legitimacy. The appellate chamber stated that referring to certain articles of law should not be enough for considering an act justified, because justification implied both legal and factual justification, which was not generally included in the appealed acts $^{12}$. Subsequently, for the purpose of enforcing the Supreme Court judgment the administrative organ issued a new act which included a justification saying that increasing the construction coefficient (parameters) and development of the area in those scopes "would not significantly change the existing urban environment urban planning parameters of which had already been exceeded by that time"13. As the justification was too poor and the Supreme Court Judgment was only formally enforced, a new lawsuit has been started.

\footnotetext{
${ }^{9}$ Art. 31.

${ }^{10}$ K. Kalichava, Construction Law, in: Legal Bases of Public. Administration, ed. by G. Khubua, K. Sommerman, Tbilisi 2016, p. 297.

${ }^{11}$ Ruling of the Chamber of Administrative Cases of the Supreme Court of Georgia of 20 IV 2017, n. BS-930-922 (2K-16).

${ }^{12}$ Ruling of the Chamber of Administrative Cases of Tbilisi Court of Appeals of 13 XI 2016, n. 3B/1944-15, pp. 27-28.

${ }^{13}$ Ordinance of the Tbilisi Mayor's Office of 22 VIII 2017, no. 1-1915.
} 


\subsection{Separate Aspects of Deregulation of the Control of Construction Permits}

Another problem in construction law is caused by other amendments aimed at bureaucracy reduction. According to those amendments the construction permits issuing authority does not have to approve the constructional project of a building; it does not check the competence of geological research; does not approve a greening project; does not check the quality of the construction materials. Fire safety issues were not agreed at the stage of issuing permit until January 1, 2017, except for the sites envisaged by civil safety legislation. The issue of changing functionality has been excluded from construction offences. Accordingly, the above processes are beyond any control. Moreover the participants of construction activities are not qualified because according to the applicable legislation, the accreditation or licensing of construction companies and other parties of the legal relationships in the construction field is no longer required.

\subsection{Insolation and Natural Lighting}

Before 2008 observation of insolation and natural lighting norms which themselves served as guarantee of protecting the human right of living in healthy environment, had been partially ensured. However, in 2008 Order \#50 on Approving the Norms and Rules of Natural Lighting and Insolation, of September 21, 2001 issued by the Minister of Urbanisation and Construction of Georgia was abolished. The above act required consideration of positive (good for health) and negative (overheating) effects of insolation on humans and rooms, at the stage of processing the construction project and urban planning decisions. Of course, abolishing the Order gives rise to many questions because there was no new regulation adopted to balance the gap. There seemed to be two possibilities of filling the above vacuum, but they are interpreted in a way as to protect the developer from facing any obstacles: the first possibility is provided in Article 35 of the Decree\#57 of the Government of Georgia on Issuing Construction Permit and Permit Conditions, which states that "if it is "necessary" the possible negative effect of a planned construction shall be assessed during the construction process". However the term "necessary" - is in practice interpreted in different ways and usually 
the permits issuing authorities do not bother themselves to asses such necessity. In most cases observance of the requirements of Article 35 becomes mandatory for the builder only after receiving the construction documentation. In such a case interpretation of the term "necessity" is still unclear because the builder will of course avoid extra costs. Based on the current practice, the above issue is checked only if claims are presented and the supervisory authority assigns such a check, based on the records of the construction documents. Another option should be Order \#1-1/251 of the Minister of Economy of Georgia on enabling the so called Soviet SNiPs (Construction Rules and Regulations) which were in force before 1992 to be applied in the construction field, until drafting new norms (including but not limited to the insolation and natural lighting norms), as long as they do not contradict the current legislation of Georgia and if there is no alternative in the national construction norms and normative acts $^{14}$. This solution should contribute to solving the problem but it has been neglected in the practice for unknown reasons.

\subsection{Daily Risks of Devaluation of Immovable Property}

The lack of control in the construction field and an exceedingly liberal approach to business activities threatens the value of the neighbouring property or the developer's property each day. There was a case when one of the developers worsened the neighbour's living conditions but later another developer also took an advantage of the weak legislation and built such a construction just in front of the above developer, which completely obliterated the right to a view and caused a significant decrease of the selling price of the property ${ }^{15}$. Moreover, experts (appraisers) determining the damages occurring in the construction field, mostly take into consideration the damage rate of the direct impact and the rehabilitation costs, as well as the violation of natural lighting norms, blocking the visible and sight area, the condition of the transportation hubs and accessibility of the territory by different emergency services including ambulance, police, fire extinguishing vehicles etc. because usually each new construction causes loading the territory with new cars while in

${ }^{14}$ https://matsne.gov.ge/ka/document/view/1210709?publication=1 (accessed: 12 I 2018).

${ }^{15}$ The RIA was performed on the project of the code https://info.parliament.ge/ file/1/BillReviewContent/135905 (accessed: 12 I 2018). 
most cases the road infrastructure is not renewed ${ }^{16}$. In other words the transportation hubs made some decades ago and considered for certain type of urban planning can no longer satisfy the requirements of the new intensity of planning. This issue is left beyond regulation while the city planning authorities usually study the transport access only in connection with the certain construction site, without paying attention to the neighbouring buildings. We should mention herein that the above factors are not taken into consideration when the lawfulness of disputed acts is checked. For example, in one of the cases the Court of Appeal stated that the conditions indicated in the plaintiff's application, referring to the worsening of the plaintiff's living conditions (limiting access to vitally important air and sun rays) in the case of building the house of [certain] dimensions and accordingly decreasing the selling/leasing market price of the house, did not constitute enough basis under substantive 1 law to declare the disputed act (a special zone agreement) null and void because of incompliance with law"17. Obviously the judges are encouraged to make such decisions by the weak statutory regulations in force. Accordingly, they are inactive and do not review the fact of infringing the "legitimate interests" of persons. In the event a physical injury or pulling down a house occurs, the construction dispute is taken to court and legal action is started in a civil law procedure with a claim demanding damages. In some cases a criminal proceeding may also be initiated in accordance with Article 187 of the Criminal Code of Georgia, which envisages responsibility for damaging or/and destruction of other person's property. However the civil and criminal law measures of protecting the individual interests of the interested party are absolutely ineffective.

\subsection{Rights of Indirect Expropriation and a Good Faith Purchaser}

According to the legal dogma, the city planning activities which involve any limitation of construction rights on a privately owned immoveable property may be assessed as an activity infringing the private ownership right and if it reaches a certain extent, it may be considered as factual

${ }^{16}$ Protocol of devaluation of a property price issued by the audit firm Bakashvili and Company, no. 2/28-2016, 12 VII 2016, p. 19 (exists in the form of a manuscript).

${ }^{17}$ Ruling of the Chamber of Administrative Cases of Tbilisi Court of Appeals of 15 XII 2015, n. 3b/1291-16. 
(indirect) expropriation ${ }^{18}$. Of course, such a restriction has to be based on the proportionality principle and social welfare, provided that appropriate compensation is considere ${ }^{19}$. The above principle is often neglected in Georgia. When new plans are approved, many of the territories of the city are blindly included in such zones where construction is not allowed. But factually those territories are high-density residential construction zones (e.g. some territories nearby Tskneti, Varketili and Tbilisi Sea which are well developed residential areas have been included in the landscape and recreational zone). Consequently numerous private owners end up with absolutely devaluated property ${ }^{20}$. Still this fact has not been legally acknowledged as indirect expropriation in accordance with Articles 208-209 of General Administrative Code of Georgia (referring to reimbursement of the damage caused by lawful and unlawful acts).

The right of private ownership is often directly related to the institute of a good faith purchaser. And good faith purchasers are often respondents (third parties) in construction disputes. For example, in the case heard by the Administrative Case Collegium of Tbilisi City Court ${ }^{21}$ the good faith purchaser was a third party who had bought the construction site with the increased building parameters already in 2015 and applied for a construction permit while the owners of the neighbouring piece of land started a lawsuit against Tbilisi City Hall and the third party. On May 30, 2017 the court of first instance satisfied the plaintiff's claim and invalidated the disputed act but the court did not explain why it did not take into consideration the good faith envisaged by Article 187 of the Civil Code of Georgia and the fact that the third party had bought the property with increased parameters and, accordingly, paid the market price for the property with the increased parameters included, which amounted 140,000 USD in accordance with the conclusion of LEPL Levan Samkharauli National Forensics Bureau ${ }^{22}$. Solely the fact that the new owner is a good faith purchaser should not prevent the court from checking the lawfulness of the challenged documents

${ }^{18}$ M. Kruś, Z. Leoński, M. Szewczyk, Prawo zagospodarowania przestrzeni, Wolters Kluwer Polska SA, Warszawa 2012, p. 27; P. Turava, General Administrative Law, Tbilisi, 2016, p. 216-220.

${ }^{19}$ M. Kruś, Z. Leoński, M. Szewczyk, Prawo..., p. 27.

${ }^{20} \mathrm{http}: / /$ maps.tbilisi.gov.ge/\#/C=44.8319241-41.7386346@Z=19 (accessed: 12 I 2018)

${ }^{21}$ See the decision of the Administrative Case Collegium of Tbilisi City Court in case \#3/1748-16, of May 30, 2017

${ }^{22}$ Certificate issued by the LEPL Levan Samkharauli National Forensic Bureau of 3 VI 2016, no. 003180116, p. 1. 
and making reasonable decisions. Nevertheless, the current legislation does not provide for appropriate guarantees for the rights of developers who fall into such a situation and are forced to apply to court in order to protect their rights on the lawfully purchased property.

We should mention that contrary to the above, in another case, ${ }^{23}$ the court took into consideration the third party's opinion regarding good faith. The court stated that if the construction parameters had not been

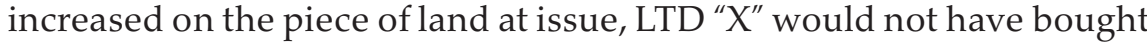
it because the old parameters did not allow the building of a multi-storey house and accordingly it would be unprofitable. Moreover, the court paid attention not only to the damages which LTD " $\mathrm{X}$ " would have suffered but also to the interests of the persons from whom the construction site had been bought. If the court invalidated the disputed individual administrative acts pursuant to the applicable legislation, LTD " $X$ " would have been entitled to demand reimbursement of the damage from the previous owners because they had sold the property with legal defects. However, the decision did not include any discussion about the possibility of claiming liability on the part of the state.

Such a diversity of approaches affects the construction business and undermines the trust in authorities issuing building permits because, as the court practice also shows, in most cases these authorities do not evaluate the important circumstances of the case or/and do not provide justification of the issued permits which is directly reflected on the rights of private owners participating in construction sector because they are not able to exercise effectively their right to ownership. Such court practice weakens the basis for developing construction business. Although, the holders of construction documents invalidated for similar reasons are entitled to reimbursement of damages by the issuer of the permit in accordance with the current legislation.

\section{Prospects of the Construction Legislation Reform}

\subsection{About the Construction Code Project}

The fundamental reform of Georgian construction law is connected with drafting the Code of Spatial Planning and Construction of Georgia

\footnotetext{
${ }^{23}$ Ruling of the Chamber of Administrative Cases of Tbilisi Court of Appeals of $22 \mathrm{X}$ 2016, no. 3/9350-15.
} 
(hereinafter referred to as the Code) that began back in 2012 and the discussions are still going on. The project of the Code was ordered by the Ministry of Economy and Sustainable Development of Georgia, with financial support of the German Society for International Cooperation (GIZ) ${ }^{24}$. There was also conducted a regulatory impact assessment (RIA $)^{25}$ on the project of the code; large-scale public discussions were held periodically, with participation of the main interest groups.

The concept of the construction law reform within the scopes of the Code is mainly based on four cornerstones: national legislative traditions; existing practical problems; the German Court practice and European Union Law expertise ${ }^{26}$. The first two cornerstones create the basis for preserving and developing the institutions already existing and tested in practice, but, at the same time, the existing norms (and the current practice) contradict the law and order, thus providing arguments for the need of fundamental changes and reform.

Regarding the implementation of certain German solutions the reform was initially based on the principle of reasonable inclusion of foreign expertise into Georgian law ${ }^{27}$. In that regard, of particular importance was the approach of German construction law to establishing a double-staged city planning system, land development, land exchanges, city planning activities (rehabilitation), and quality requirements for buildings and construction materials, and the like. The guarantee that German solutions regarding the above would be included in Georgian law was the fact that Gerd Winter, Professor of Public Law of Bremen University, was intensively participating in the working group drafting the $\operatorname{Code}^{28}$. Cooperation with Professor Winter included the analysis of the current legislation, legal dogmas and court practice of Germany. The main part of the Code was drafted in that period. In the course of the reform European Union Law experience was also taken into account, which implied to support approximation of Georgian legislation with

\footnotetext{
${ }^{24}$ https://info.parliament.ge/\#law-drafting/13042 (accessed: 12 I 2018).

${ }^{25}$ https://info.parliament.ge/\#law-drafting/13042 (accessed: 12 I 2018).

${ }^{26}$ K. Kalichava, Impact of Construction Law Reform..., pp. 43-44.

${ }^{27}$ It must be noted that there is an immense influence of German law on the Georgian one (both, in regard to private and public law). The General Administrative Code of Georgia and the Administrative Procedure Code of Georgia adopted in 1999 were developed based on the system instututions and notions of German law.

${ }^{28}$ Within the framework of the project, Prof. Dr. Gerd Winter paid several visits to Tbilisi; also, Associate Professor of the Ivane Javakhishvili Tbilisi State University, Koba Kalichava had three working visits in Bremen to visit Prof. Dr. Gerd Winter.
} 
the directives and regulations defined in the European Union Association Agreement (AA). In this regard, the Code will contribute to the process of implementing Directives \#2001/42,\#2003/35, \#2011/92, \#92/57, \#2010/31 and regulation \# 305/2011 in the Georgian legislative system.

The draft Code has been presented to the Parliament of Georgia and hopefully, it will be adopted soon ${ }^{29}$.

\subsection{The Constitutional Framework of the Reform}

The need for a reform of Georgian construction law was basically conditioned by internal constitutional obligations. Naturally, the basic rights guaranteed under the Constitution and fundamental principles of a modern state shall be continued. If we trust the thesis of Fritz Werner saying that "administrative law is concretised constitutional law", 30 then the correlation becomes clear. In a democratic and legal state, public administration (and its regulatory administrative legislation) shall undertake the function of ensuring and guaranteeing the fundamental rights and freedoms and a modern market economy system. The above function can be realised in everyday life through administrative legislation (general and special). Accordingly, a reform of such laws becomes a part of internal constitutional obligations from the very beginning.

From that perspective, sharing the solutions adopted under German and European Union laws without which the reform could not have been successful in the transitional period, still had the ancillary function of concentrating the intellectual streams. In the environment where there existed a constitution, the reform was carried out in such a way that the framework of the identity of the basic law of the country and sovereignty should remain unaffected ${ }^{31}$. We believe that this principle should work in the same way in any supranational system where there

\footnotetext{
${ }^{29}$ https://info.parliament.ge/\#law-drafting/13042 (accessed: 12 I 2018).

${ }^{30}$ F. Werner, Verwaltungsrecht als konkretisiertes Verfassungsrecht, DVBl, 1959, p. 527 et seq.

${ }^{31}$ For example, the creation of the institution of alternation, which already operates in German construction law was rejected in the project of the Construction Code of Georgia due to the fact that some of the local lawyers regarded it not to be in compliance with article 21 of the Constitution of Georgia (right to property). I will not go deep into arguing on the credibility of the latter argument. Bringing up this matter only aimed at underlining that the constitutional framework was always an integral aspect of the legislative drafting process.
} 
is "enough space"32 for determining economic, cultural and social policy for member states, maintaining "constitutional identity" ${ }^{33}$ and a possibility of positive structural changes ${ }^{34}$.

In regard to the constitutional framework of the reform we should basically discuss the fundamental human rights as the right to be protected from the state and as the state's positive obligation of protecting the holder of the right from any interference of third parties. Under the Constitution of Georgia, the right of ownership as well as the right of living in the healthy and safe environment is guaranteed ${ }^{35}$. In the case of the right of ownership the Constitution of Georgia protects ownership as the institutional guarantee (protecting the rights of builders) or as the guarantee of person's right (protecting the neighbours' rights) ${ }^{36}$. On the other hand, ownership is not just a right but it is an obligation too and is limited by public interests ${ }^{37}$. Accordingly, the construction legislation should be constructed in such a way that it should somehow balance the tripolar relationships (permit seeker, permit issuer, interested party). Article 29 of the redrafted constitution of Georgia includes a very important provision where the right of using "natural environment and public space" is provided in the perspective of protecting individual subject's right. Therefore, the legal essence of the interested party in the above-mentioned tripolar relationships has become wider.

\subsection{What is the Golden Mean between the Freedom of Construction Business and Others' Interests, according to the Construction Code Provisions}

Due to the fact that construction is considered to be the essential segment of economy of Georgia, its interest was one of the fundamental positions of the group working on the Construction Code. The case was that the working group should not recommend to the government any regulations which might prejudice the success of the whole process of the reform. Thus, there were drafted regulations which would ensure freedom of business on the one hand, and would not infringe other

\footnotetext{
${ }^{32}$ BVerfGE 123, p. 267 et seq.

${ }^{33}$ BVerfGE 123, p. 267 et seq.

${ }^{34}$ BVerfGE 126, p. 286 et seq.

${ }^{35}$ Art. 12 and 37 (in new edition see art. 19 and 29).

${ }^{36}$ K. Kalichava, Construction Law, p. 260.

${ }^{37}$ Ibidem.
} 
public or private interests (e.g. living in healthy environment, protection of cultural heritage, ecological, etc.), on the other hand.

Therefore, freedom of construction business, as provided in the Code, should mean moderate regulation/deregulation. The point is that the policy of imbalanced deregulation affects the freedom of business itself negatively, ${ }^{38}$ because when the mechanisms of considering multipolar interests are wasted the customers lose trust in the developer and often its business becomes subject to endless disputes (deficiency of acceptability). Simultaneously, as a result of deregulation, the developer is not in a close cooperation regime with the government, or the cooperation with state bodies is rather formal (deficiency of co-operationalism). The activities of the developer encouraged by deregulation often contradict the interests of other developers (either faithful or unfaithful) (the effect of negative feedback of deregulation). While in some cases the lack of legislative limitations may encourage developers to exercise their own business interests, in other cases their interests may be infringed by the same reason if another developer decides to start a new construction on the neighbouring plot (e.g. if the construction parameters are increased as a result of "coefficient trading" and a multi-storeyed building is built on a low intensity construction zone, another developer may buy an even bigger construction coefficient and build a building which will block the view and violate the insolation and natural lightening norms, etc.).

\subsection{What does the Code provide regarding the Purpose of Moderate Regulation/Deregulation of the Construction Field?}

The draft Code contains some novelties with respect to the moderate regulation/deregulation of construction business:

(1) One of the most important achievements of the Code is restriction of opportunities for so called "Coefficient trading". Namely, according to the Code, exceeding the coefficients determined by the urban construction plans and basic provisions will not be allowed in certain cases. An exception will be allowed only based on a detailed urban construction plan. Therefore, such an exception will not be commercialised and will be allowed only in the event when it is compensated with appropriate

${ }^{38}$ Further see, K. Kalichava, Strategic Aspects for Fulfillment of Georgian Legislation on Environment Security, "Law Journal" 2012, no. 2, p. 117. 
activities which, according to the code, shall include "ensuring observance of healthy living and working conditions requirements and avoidance of adverse impact on the environment, satisfying transport, engineering and infrastructural requirements or their improvement."

(2) According to the Code, the planning concept shall be strengthened while issuing a construction permit. In other words, the Code allows issuing a construction permit in two cases: a) if a piece of land is located within the area of a detailed urban construction plan (the planned internal or external territory) and the construction permit is granted in accordance with the plan requirements; b) if a piece of land is located within a developed system area (unplanned internal territory) and the construction permit is granted according to the factual construction environment, if it exists, while applicable urban construction plans are taken into consideration. Taking into account the fact that the possibility of increasing coefficients is restricted in certain cases and the factual construction scales will not be satisfactory for the developers in most cases, the permit seeker will of course have to provide a detailed urban construction plan which will also contribute to an organised urban development.

(3) The Code provides a solid legal basis for private persons to be entitled to make a detailed city construction plan themselves, which is an expression of new public management (NPM) ${ }^{39}$ and good governance ${ }^{40}$. Allowing the developers to initiate a detailed urban construction plan is directed at transferring the government functions to private persons as well as ensuring maximum involvement of social institutions in the process of product creation (social welfare production), which is a tool for realisation of the idea of a small state.

(4) Along with private persons, the local city construction plans may also be initiated and realised by the central agencies of the state government. The goals of such a provision are: a) to enable the state government to create a one stop shop by zoning the special regulation and for encouraging investment projects, sell to the investors pieces of lands already planned by them; b) throughout the transitional period, until municipal structures are strengthened, the government should be entitled to take control over territories available for intensive constructions (now such territories are Gudauri, Bakuriani, Bakhmaro, Ureki). In such cases the independence of the self-government is guaranteed by

${ }^{39}$ Regarding public management see futher, L. Izoria, Contemporary State, Contemporary Administration, Tbilisi 2008, pp. 94-109.

${ }^{40}$ About good governance see, ibidem, pp. 208-217. 
the involvement of respective municipal organs in the planning process and also, by the guiding principles determined in the Code which shall be mandatory as applicable law.

(5) The Code renounces the bad practice and according to its provisions a consent of the owners will not be required for a detailed city construction plan. The former practice, on the one hand, limited and made a municipality incapable in its exclusive authority to accomplish city-planning and on the other hand created obstacles for accomplishing interesting urban projects. In the scopes of the new approach protection of the owners' interests is guaranteed by establishing formal administrative proceedings and introducing the mechanisms of demanding and awarding damages.

(6) As regards the mechanisms of reimbursing damages caused by adopting, amending or invalidating urban construction plan ${ }^{41}$, if the urban construction plans worsen legal status of an owner he/she shall have right to demand damages from the state. In this regard the current construction legislation of Georgia does not provide for any special regulation of reimbursement for the damage. There applies only a general rule determined by the General Administrative Code of Georgia about reimbursement of the damage caused by lawful or unlawful administrative act or its invalidation. The problem of the general rule is that (a) it does not define the concrete basis for demanding and awarding the damage i.e. from what basis the land owner's initial right originates (it can be an urban construction plan or the existing construction environment); (b) it does not determine the limitation period for the initial right of using the piece of land; (c) it does not determine the special limitation period for demanding reimbursement of the damage. The code regulates the above issues in details and introduces regulations which comply with the principles of a transparent state and a rule of law.

(7) Regulating city-planning professions is another novelty of the code and its accompanying legislation. In this regards there are essential deficiencies in the current legislation of Georgia. According to the current regulations, any person is entitled to draw up and sign a city-planning and permission documentation. Following the tracks of European approaches ${ }^{42}$ the Code changes the above rule and introduces the

${ }^{41}$ See, K. Kalichava, Permission Control of Contraction Activity (need of reform and perspectives), "Journal of Administrative Law" 2016, no. 2, p. 99.

42 See, e.g., W. Hoppe, Ch. Bönker, S. Grotefels, Öffentliches Baurecht, München 2010, p. 457 . 
institute of certified city planners, architects and building engineers. At first sight increasing the "qualification requirements" for the applicants tightens the freedom of construction with regard to the burden of proof and sharing responsibility. However, qualified participation of the permit seeker in so called "procedural works" does not itself mean to be a repression because such involvement of the permit seeker serves its own interests too and contributes to investigate the 'Non liquet ${ }^{\prime 43}$ situations. It does upgrade the quality of legal security, decreases the probability of identifying defects and speeds up administrative proceedings ${ }^{44}$.

(8) The Code introduces clearly defined regulations of temporary suspension of the right of use i.e. "if the city construction plan is being elaborated, the authorised permit issuing organ may pause the administrative proceeding on issuing a construction permit for 4 months, based on a reasonable refusal and in case there is a general plan of using land, it may be prolonged, maximum for three months. The Code also provides for the possibility of declaring moratorium on the planning territories. The purpose of those mechanisms is to prevent constructions which might become inappropriate objects in the future in case of approving the plan being drafted. If the proceedings are not renewed after the fixed term, the permit seeker may demand an award of damages.

(9) The Code introduces public availability of spatial planning and urban construction plans, which is aimed at ensuring reliable information needed for the realisation of an ownership right and investment. That mechanism, of course, shall not limit the authority of demanding public information pursuant to the General Administrative Code of Georgia.

(10) The Code regulates the issue of land exchange, which is also an expression of new public management (NPM) as it is directed at creating a general welfare product. Namely, it aims to provide legal and factual basis for fulfilling the requirements of an urban construction plan, whenever there is a necessity to use a privately owned piece of land or a part of it in different forms including equal exchange, allowed reduction (when the value of the piece of land still increases), configuration change or/ and compensation. Generally, using these mechanisms should provide a better urban value and a more healthy residence structure.

43 "Non liquet' - facts to be investigated, which has a great impact on the legal outcome, see, Th. Berg, Beweismaß und Beweislast im öffentlichen Umweltrecht, Baden-Baden 1995, p. 74 et seq.

${ }^{44}$ See, K. Kalichava, Permission Control..., pp. 95-96. 
(11) The Code introduces the mechanisms of a partial permit and preliminary decision. A partial permit may be issued on the basis of the construction concept, on a zero-cycle construction, and shall have the characteristics of an individual administrative-legal act. A preliminary decision will be issued on the architect's sketch of a building and shall have the characteristics of an administrative promise. Also, the Code states that the preliminary decision or/and a partial permit cannot be issued in cases when presenting full permit documentation is required.

(12) The Code broadens the possibilities of using suspensive effect. Namely, the Code sets forth that "at the request of an interested party, the authorised administrative organ or court may suspend an individual administrative act fully or partially, if a reasonable doubt about the lawfulness of the disputed act exists; or if immediate enforcement of the act may substantially damage the interested party or make it impossible to protect its legitimate rights and interests". Accordingly, although appealing a construction permit does not automatically suspend it, under the new Code, contrary to the current legislation, not only the court but also the issuing body will have the authority to suspend, in exceptional cases, the permit it has issued if the above reasons exist.

(13) The Code introduces a completely new type of supervision supervision by an accredited organ of inspection. If it is chosen, the construction site may be controlled by the public supervision organ only within 5-10 days after certain construction stages or final exploitation of a building is approved. In other cases supervision is restricted unless there is a reasonable claim of an interested party or the demand for an inspection by such accredited organ.

(14) And finally, one of the main achievements of the Code is an appropriate legal basis created for ensuring the quality of the construction. This is because as a result of the deregulation implemented in the permission legislation recently, this sphere has been practically left out of control. In this regard, the Code offers a relevant statutory organisation that will serve as a basis for implementing appropriate technical regulations. These may include regulations such as $\mathrm{CEN},{ }^{45} \mathrm{ICC}^{46}$ or ISO,${ }^{47}$ which address building facilities as well as building materials ${ }^{48}$.

${ }^{45}$ European Committee for Standardization.

${ }^{46}$ International Code Council.

${ }^{47}$ International Organization for Standardization.

${ }^{48}$ EU 98/34/EG directive refers to the technical norms prepared by organisations given in the first annex. 


\section{Conclusions}

The bad experience of the Soviet period, on the one hand, and the post-Soviet challenges in terms of business encouragement and radical deregulation, on the other hand, have determined the need for a radical reformation of Georgian construction legislation. That is why, the Construction Code draft which is focused on such a reform is mostly regulative and sets new rules of the game in the bipolar relationships for both, permit issuing administrative organs and permit seekers, while in tripolar relationships it strengthens the tools of protecting the third parties' (generally neighbours') rights. It should be mentioned that according to the Code, correct application of regulatory approaches, contrary to deregulation, creates a basis for legal security and stability; contributes to the realisation of the principles of coordinating multipolar interests, sustainable development and acceptability in urban construction planning.

\section{MODERN DEVELOPMENT TENDENCIES OF GEORGIAN CONSTRUCTION LAW}

\section{Sum mary}

The problems and prospects of development of the modern Georgian Construction Law are reviewed in the article. Negative tendencies of the construction coefficient trading and negative influence of the above practice in the urban construction are discussed as a problem. In connection with the above, the non-uniform court practice makes the vague legal grounds of coefficient trading even more obscure.

The article reviews the legislative changes aimed at bureaucracy reduction implemented in the Georgian Construction Law which brought negative results in addition to positive aspects. In particular, the authorities issuing permits do not approve the structural designs, do not evaluate the competence of the geological survey and more importantly, the quality of construction materials is not checked. Within the framework of the same reform, the regulation obligating to observe the standards of sun exposure and natural lighting for adjacent buildings during construction was revoked since 2008.

It is mentioned in the article that the above deregulation, as well as vague legislative regulations cause devaluation of the cost of adjacent buildings of the construction. The authors of the article equalize this fact to indirect expropriation with the difference that no compensation is paid for restoration of their rights and the affected citizens have to engage in procrastinated litigations. Precedents from the court practice are reviewed in the article on this issue which make it clear that the documents issued by administrative authorities are often unsubstantiated. The prospects of the reform of the Georgian construction legislation and Code of Spatial Planning and Construction of Georgia are reviewed in the article.

Keywords: construction law - building law - expropriation - construction legislation 